\title{
Business model diversification in the sharing economy: The case of GoMore
}

\author{
Hugo Guyader ${ }^{\text {a, * }}$, Laura Piscicelli ${ }^{b}$ \\ a Department of Management and Engineering, Linköping University, SE-58183, Linköping, Sweden \\ b Copernicus Institute of Sustainable Development, Utrecht University, 3584 CS, Utrecht, the Netherlands
}

\section{A R T I C L E I N F O}

\section{Article history:}

Received 31 January 2018

Received in revised form

3 January 2019

Accepted 11 January 2019

Available online 14 January 2019

\section{Keywords:}

Sharing economy

Business model diversification

Business model portfolio

Shared mobility platform

\begin{abstract}
A B S T R A C T
This paper improves our understanding of the rise of the sharing economy by shedding light on the current trend in the mobility sector for new firms to operate different business models simultaneously. A shared mobility platform is used as a case study to examine the underexplored process of diversification into a business model portfolio, and test the theoretical proposition that successful business model configurations maximize the existing resources of a firm to establish hard-to-imitate capabilities and create sustainable competitive advantage.

Data collection was conducted through interviews with key informants from the platform management team and a document analysis. The analysis shows the evolution, diversification, and expansion of the sharing economy startup from a non-profit ridesharing website to a for-profit matchmaking platform offering peer-to-peer (P2P) mobility solutions (ridesharing and short-term car rental) alongside business-to-consumer (B2C) access-based services (long-term leasing).

The analysis suggests that each new service subsequently offered by the case firm aimed to increase the supply of peer providers in its existing P2P business models. The business model portfolio relies on six key resources (member community, platform technology, user data, customer support, local management teams, and partners) and three key capabilities (leverage of the community's assets, technological improvement, and user engagement), which are shared and redeployed across business models and geographic locations to improve matchmaking quality, enable growth, and increase profits.
\end{abstract}

(c) 2019 Elsevier Ltd. All rights reserved.

\section{Introduction}

In recent years, there has been a proliferation of online platforms providing consumers with temporary access to a plethora of goods and services in many sectors (Owyang, 2016). Often framed under the banner of the "sharing economy," much research on these platforms has focused on the analysis and classification of their underlying business models: that is, "the design or architecture of the value creation, delivery, and capture mechanisms" they employ (Teece, 2010: 172). In the shared mobility sector, for example, "carsharing," "bikesharing," and "ridesharing" were identified as different business model categories (Cohen and Kietzmann, 2014). In practice, however, many sharing economy platforms operate two or more business models at once-a so called business model portfolio (Aversa et al., 2017). For example,

\footnotetext{
* Corresponding author.

E-mail address: hugo.guyader@liu.se (H. Guyader).
}

Dutch platform MyWheels-a 25-year-old business-to-consumer (B2C) carsharing firm-now makes it possible to choose between renting their branded cars or one from a neighbor (i.e. peer-to-peer [P2P] carsharing). Turo-a P2P carsharing platform-also enables professional rental agencies to list their car fleet on the platform, thereby diversifying its revenue streams (i.e. 10\% commission on each commercial rental compared to the $25 \%$ commission applied to P2P rentals) and increasing its overall supply of cars available for rental. Such business model diversifications aim to enhance the platforms' competitiveness and performance by increasing the diversity and availability of rental cars.

However, operating a business model portfolio is extremely difficult (Casadesus-Masanell and Tarziján, 2012; Markides and Oyon, 2010; Snihur and Tarziján, 2017). On the one hand, different business models can work in synergy and mutually reinforce one another. On the other hand, they can be in direct conflict and lead to resource dilution (i.e. defocus resources from core activities) or the cannibalization of the original business model (Aversa et al., 2017). For example, ride-hailing platform Uber failed 
to successfully operate a long-term car rental service for its drivers between 2015 and 2017 ("Xchange Leasing"), as well as a shortterm car rental service for its riders ("Uber Rent"-in partnership with GetAround) that was shut down in 2018 only six months after its launch.

Business model diversification remains a rather underexplored phenomenon (Aversa and Haefliger, 2016). Researchers have yet to uncover the complexity of operating interrelated business models and their underlying mechanisms-particularly in the context of the sharing economy. Despite the increasing number of platforms that simultaneously deploy more than one business model in the shared mobility sector (Frenken, 2017), little research has examined how platform operators successfully diversify into a business model portfolio. It is also not known how sharing economy firms can benefit from a combination of different business models. Moreover, Kumar et al. (2018) called attention to the lack of studies on the strategies-such as business model diversification-that sharing economy firms can use to reach the necessary critical mass of peer providers and consumers.

The purpose of this paper is to fill these knowledge gaps by empirically exploring business model diversification in the sharing economy. GoMore-an online platform with two million members that offers three different mobility services-was chosen as a case study to explain why and how a sharing economy platform successfully diversifies into a portfolio of business models. The analysis provides empirical evidence to Aversa et al.'s (2017) theorisation that high-performing business model configurations maximize the existing resources of a firm and develop hard-to-imitate capabilities, thereby generating growth and profit. The GoMore case also shows that business model diversification can specifically be used by sharing economy platforms as a strategy to balance supply and demand in online marketplaces.

The paper is organized as follows. Section 2 examines shared mobility platforms and reviews the strategy literature on business model diversification. Section 3 describes the methodology of the study and introduces GoMore. The results are presented in Section 4 , where we describe the multiple business models of GoMore and provide a detailed account of their adoption over time. This is followed by a discussion of the key findings in Section 5, assessing the key resources and capabilities underlying GoMore's portfolio of business models. In Section 6, we summarize the contribution this study makes to the understanding of business model portfolios in the sharing economy, and we acknowledge the limitations of the study and suggest some directions for future research.

\section{Shared mobility platforms}

The recent rise of the sharing economy has triggered a dramatic increase in the number of online platforms that enable temporary access to a variety of goods and services made available by traditional B2C firms or private individuals. This section focuses on sharing economy platforms operating in the mobility sector and their underlying business models. Adding to the existing literature on shared mobility business models, we review strategy literature on business model diversification that is relevant to the examination of the emergence of business model portfolios in the sharing economy.

\subsection{The sharing economy}

In the last decade, mostly due to digital technologies and the emergence of more collective forms of consumption, people have changed the way they gain access to products and, in particular, their attitude towards ownership (Bardhi and Eckhardt, 2012; Fournier et al., 2013; Perren and Kozinets, 2018; Zervas et al., 2017).
The emergence of sharing economy platforms lies in their promises to provide economic, social, and environmental benefits by using existing resources more efficiently and reducing waste (e.g., Martin and Upham, 2016). Botsman and Rogers (2010: xv) initially adopted the term collaborative consumption to describe "the reinvention of traditional market behaviors - renting, lending, swapping, sharing, bartering, gifting - through technology, taking place in ways and on a scale not possible before the Internet." In their seminal book What's Mine is Yours, the authors evoked the proliferation of a variety of online platforms that enable people to rent a car by the hour or share their spare bedroom with strangers as an antidote to overproduction and overconsumption. The label "sharing economy" later became popularized by the media as an umbrella term for business and consumption practices that are based on sharing underutilized resources (e.g., goods, services, and spaces) for free or for a fee, typically enabled by online platforms and peer communities. These included activities as different as renting designer bags (Philip et al., 2015) and the redistribution of unwanted items (Martin and Upham, 2016). Not surprisingly, such a loose use of the term sharing sparked a lively debate about what should be grouped under the sharing economy banner. Many have criticized the semantics of the sharing economy, wherein the words and ideas of community belonging and genuine sharing are associated with forprofit companies and their self-interested activities (Belk, 2014; Eckhardt and Bardhi, 2015).

The conceptual ambiguity of the sharing economy is due, according to Frenken (2017), to its position at the intersection of three contemporary economic trends: 1 ) the circular economy, 2) the access economy, and 3) the P2P economy (Fig. 1). First, the circular economy encompasses a set of activities and practices aimed at minimizing waste, reducing resource depletion in the production of new goods, extending a product's life through maintenance and repair, reusing existing products by sharing and remanufacturing them, and recycling products efficiently (Kirchherr et al., 2018; Stahel, 2016). In summary, the circular economy facilitates the recirculation of existing resources from where they are underutilized or no longer wanted to where they are needed or can be used more efficiently.

Second, the access economy refers to the shift from private ownership (e.g., purchase) to temporary access to goods and services (e.g., rental) in exchange for a payment based on membership and/or usage (Bardhi and Eckhardt, 2012; Lovelock and Gummesson, 2004; Schaefers et al., 2016). This also resonates

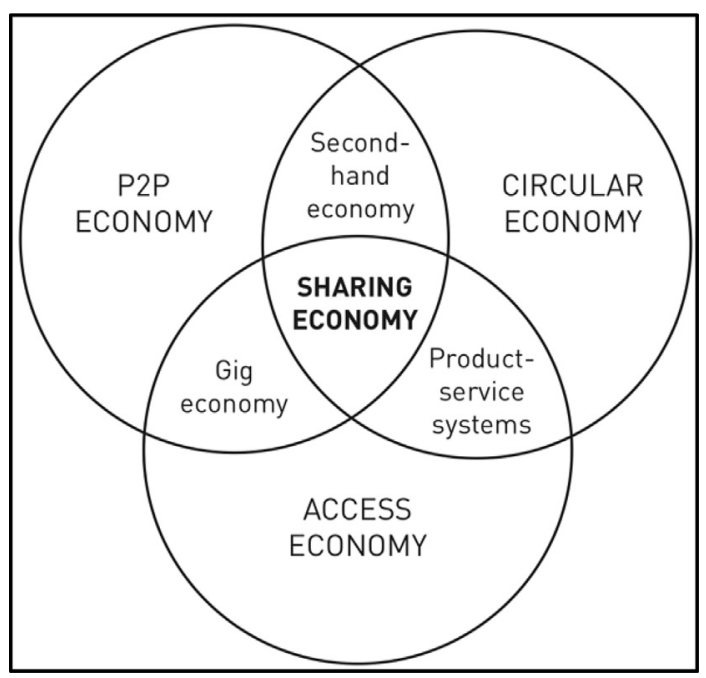

Fig. 1. The sharing economy and its related concepts (adapted from Frenken, 2017). 
with the concepts of non-ownership services (Moeller and Wittkowski, 2010), product-service systems (PSS; Mont, 2002; Reim et al., 2015), and product-sharing services (Johnson et al., 1998) where multiple customers sequentially share the usage of a good owned by a firm. Zipcar is often used as an example to illustrate how consumer participation in commercial carsharing programs is largely driven by self-interest and utilitarian motives (Bardhi and Eckhardt, 2012; Lamberton and Rose, 2012; Schaefers et al., 2016).

Third, the P2P economy is based on the same network effects as the P2P file-sharing revolution with the critical difference that individuals also share offline. That is, people use online platforms to organize exchanges, eventually meeting each other directly (e.g., Vaskelainen and Piscicelli, 2018). Charging a matchmaking fee for each P2P exchange, firms take up the role of facilitators that make it easy, convenient, and trustworthy for peer providers and consumers to participate in collaborative consumption (Belk, 2014; Benoit et al., 2017; Guyader, 2018; Hamari et al., 2016; Perren and Kozinets, 2018; Philip et al., 2015; Piscicelli et al., 2015, 2018; Wilhelms et al., 2017; Zervas et al., 2017). In P2P markets, there must be enough peer providers to offer products and services and enough consumers to buy them; thus, sharing economy firms must reach a critical mass of platform users to effectively match supply and demand (Kumar et al., 2018). The more participants there are, the greater the network effects, and both sides of the platform benefit from positive externalities (Einav et al., 2016; Evans and Schmalensee, 2010; Muzellec et al., 2015).

Most of the initiatives that are generally considered to be part of the sharing economy fit into one or more of these socio-economic trends. For example, the carsharing platform Zipcar is a prototypical form of access-based consumption delivered via a commercial PSS; the ride-hailing platform Uber facilitates P2P exchanges and on-demand mobility services, thereby belonging to the gig economy category; and Drivy, a platform that enables people to lend and borrow each other's cars, simultaneously exhibits aspects of P2P, access, and circular economies.

\subsection{Shared mobility business models}

Recently, there have been some attempts to map the sharing economy based on the different sectors in which firms operate (e.g., Owyang, 2016) or the business model they adopt. Many studies have focused on the different business models deployed in the mobility sector, as this is one of the most prolific areas in the sharing economy (e.g., Cohen and Kietzmann, 2014; Münzel et al., 2017; Shaheen et al., 2016). In short, the most prevalent shared mobility business models are based on the socio-economic trends of the access economy and the P2P economy (Fig. 1).

While leasing services offering long-term car rentals in consumer markets (i.e. not B2B) represent the oldest business model providing an alternative to personal vehicle ownership, more recent shared mobility services delivered through commercial PSS offer the opportunity to pick up cars from a fleet for use on an hourly basis (i.e. shorter than leasing services) and return it to the same location (i.e. roundtrip carsharing), to a different station (i.e. one-way carsharing), or anywhere in a designated city area (i.e. free-floating carsharing; Cohen and Kietzmann, 2014; Münzel et al., 2017; Schaefers, 2013; Shaheen et al., 2016). The rental/access business model is based on monthly or yearly membership fees, combined with usage costs per hour and per kilometer (e.g., Lovelock and Gummesson, 2004). Most recent shared mobility services such as bikesharing, or scooter-sharing are also access/ rental business models based on commercial PSS.

Eventually, shared mobility services facilitated by online platforms such as P2P car rental and ridesharing services offer access to mobility through matching supply and demand (Cohen and Kietzmann, 2014; Münzel et al., 2017; Shaheen et al., 2012, 2016). Ride-hailing, ride-splitting, and taxi services offered by Transportation Network Companies (e.g., Uber) are also platform business models based on P2P transactions. Due to space considerations, we focus here on shared mobility business models relevant for the subsequent case analysis and discussion (excluding traditional public transportation and rail services, employee vanpooling, bikesharing, scooter-sharing, and TNCs).

\subsubsection{Business-to-consumer leasing}

Fleet management firms or car dealerships offering contractual leasing services of vehicles to other firms or to private customers were the precursors of the sharing economy, providing the benefits of car ownership without its burdens (Johnson et al., 1998; Lovelock and Gummesson, 2004). Essentially, it is an alternative to financing a purchase by credit. Car leasing customers acquire permanent use of a car over a long period (from six months to several years); thus, they perceive the car as their own property (i.e. psychological ownership; Peck and Shu, 2018), while legal ownership remains with the firm. Leasing services are B2C solutions based on PSS (Frenken, 2017; Mont, 2002).

\subsubsection{Peer-to-peer car rental}

Peer-to-peer car rental (or P2P carsharing) is defined as enabling car owners to rent out their private vehicles to other drivers for a limited period of time (Shaheen et al., 2012, 2016). Platforms such as Snappcar and Drivy in Europe or Turo in the U.S. facilitate the match between car owners and non-owners and provide customer support, insurance, and supporting technology, typically in exchange for a service fee and a commission (Cohen and Kietzmann, 2014; Münzel et al., 2017; Shaheen et al., 2012, 2016; Wilhelms et al., 2017).

\subsubsection{Ridesharing}

Ridesharing (or carpooling) is defined as a joint trip where drivers offer empty seats in their car or van to other passengers without a profit motive (Chan and Shaheen, 2012; Cohen and Kietzmann, 2014; Guyader, 2018). Passengers contribute to travel expenses but do not remunerate the driver (Shaheen et al., 2016). A successful shared ride between long-distance travelers needs coordination regarding itineraries and the place and time of pick-up and drop-off (Chan and Shaheen, 2012; Furuhata et al., 2013). The coordination between drivers and passengers is facilitated by ridesharing platforms in exchange for a service fee and/or a commission, or for free when operated by grassroots or non-profit organizations.

This brief overview of the most common shared mobility business models showcases the paradigm shift in the mobility sector from selling car ownership to offering temporary use of a car through access-based services. A firm typically adopts one of the described business models and tailors it (e.g., in terms of value proposition and revenue model) to satisfy the needs of a particular customer segment. However, as mentioned in the introduction, anecdotal evidence suggests that some sharing economy platforms have begun deploying more than one business model simultaneously: that is, they operate business model portfolios. While the shared mobility sector appears to be particularly prone to business model diversification, there is a lack of studies on this phenomenon as well as on the benefits and challenges for platforms that operate

\footnotetext{
${ }^{1}$ For an overview and a more detailed comparison of shared mobility business models see Cohen and Kietzmann (2014), Munzel et al. (2017), and Shaheen et al. (2016).
} 
multiple business models at once.

\subsection{Business model diversification}

In the last decade, the business model concept has attracted increasing attention in both scholarly literature and business practice (Massa et al., 2017). Although there is no universally accepted definition, a business model broadly describes how a firm creates, delivers, and captures (i.e. monetizes) value (Teece, 2010). Changes in the way that a business model is implemented (e.g., the adoption of a transaction fee or a subscription model) are the results of operational-level tactics. The selection of a particular business model to compete in the market (e.g., a carsharing versus a P2P car rental business model) is an expression of the firm's business strategy (Casadesus-Masanell and Ricart, 2010; Reim et al., 2015).

In the strategy literature (Table 1), some research has been done on the diversification of firm activities into a "business model portfolio" (Sabatier et al., 2010) that combines different modes of value creation, delivery, and capture as opposed to other traditional diversification strategies (i.e. horizontal, vertical, and geographical diversification). Aversa and Haefliger (2016) contend that a firm deploys a business model portfolio when it engages with different (i.e. at least two) ways of creating and/or capturing value. Put in the context of the sharing economy, a firm can develop a business model portfolio by adding different platform-based P2P business models, commercial PSS (i.e. B2C interactions), or a hybrid of both (Frenken, 2017). Such business model diversification is defined by Aversa and Haefliger (2016: 3) as "the activity of establishing, expanding, reducing, and eventually terminating business model portfolios."

According to Aversa et al. (2017), a "synergetic" business model diversification entails establishing a fit between the activities of each business model, as well as across multiple business models. On the one hand, Markides et al. (2004, 2010, 2013) have shown that two business models can compete with one another and new business models should be separated from existing ones to avoid conflicts, but also to "exploit potential synergies and achieve true ambidexterity." (Markides and Oyon, 2010: 30) On the other hand, sharing inputs, transferring resources, and exchanging partners

Table 1

Business model diversification literature.

\begin{tabular}{|c|c|c|c|c|}
\hline Authors & $\begin{array}{l}\text { Concept of } \\
\text { interest }\end{array}$ & Definition & Contribution & $\begin{array}{l}\text { Research } \\
\text { approach }\end{array}$ \\
\hline $\begin{array}{l}\text { Aversa and Haefliger } \\
\quad(2016)\end{array}$ & $\begin{array}{l}\text { Business model } \\
\text { diversification }\end{array}$ & $\begin{array}{l}\text { A firm that "engages with different (i.e. at least two) } \\
\text { ways of creating and/or capturing value, each of which } \\
\text { is associated with a distinct monetization mechanism. } \\
\text { Business model diversification is the activity of } \\
\text { establishing, expanding, reducing, and eventually } \\
\text { terminating business model portfolios." (p.3) }\end{array}$ & $\begin{array}{l}\text { In addition to the three traditional diversification } \\
\text { strategies-vertical (i.e. integrating other players in the } \\
\text { value chain), horizontal (i.e. offering additional } \\
\text { products/services), and geographic (i.e. expanding into } \\
\text { other countries/regions)-firms can engage in business } \\
\text { model diversification through a portfolio combining } \\
\text { different modes of value creation and value capture, } \\
\text { thus implying distinct mechanisms of customer } \\
\text { engagement. }\end{array}$ & $\begin{array}{l}\text { Single case } \\
\text { study } \\
\text { (Netflix) }\end{array}$ \\
\hline Aversa et al. (2017) & $\begin{array}{l}\text { Business model } \\
\text { portfolio }\end{array}$ & $\begin{array}{l}\text { A firm engaging in at least two ways of creating and/or } \\
\text { monetizing value. }\end{array}$ & $\begin{array}{l}\text { "Synergetic" business model diversification enables } \\
\text { companies to maximize existing resources across } \\
\text { multiple activities (e.g., increased capacity utilization } \\
\text { and decreased redundancy), develop key capabilities } \\
\text { (e.g., competitive advantage), access new valuable } \\
\text { assets, and reduce risk in uncertain environments. The } \\
\text { different business models can be in direct conflict with } \\
\text { one another resulting in cannibalization and resource } \\
\text { dilution. }\end{array}$ & $\begin{array}{l}\text { Multiple } \\
\text { case studies }\end{array}$ \\
\hline $\begin{array}{l}\text { Casadesus-Masanell and } \\
\text { Tarziján (2012) }\end{array}$ & $\begin{array}{l}\text { Complementary } \\
\text { business models }\end{array}$ & $\begin{array}{l}\text { The firm develops business models that are mutually } \\
\text { reinforcing, turning otherwise unviable possibilities } \\
\text { into profitable opportunities and building sustainable } \\
\text { competitive advantage. }\end{array}$ & $\begin{array}{l}\text { Interrelated business models are diversified to reduce } \\
\text { risks (e.g., drop in demand), and they share resources } \\
\text { (e.g., maximizing utilization) and networks to benefit } \\
\text { from economies of scale and scope, thereby increasing } \\
\text { profitability and growth. }\end{array}$ & $\begin{array}{l}\text { Single case } \\
\text { study (LAN } \\
\text { Airline) }\end{array}$ \\
\hline $\begin{array}{l}\text { Markides (2013); } \\
\text { Markides and Charitou } \\
\text { (2004); Markides and } \\
\text { Oyon (2010) }\end{array}$ & $\begin{array}{l}\text { Competing } \\
\text { business models }\end{array}$ & $\begin{array}{l}\text { Established players can respond to market disruptors } \\
\text { by adopting a new business model next to their existing } \\
\text { one. }\end{array}$ & $\begin{array}{l}\text { Two business models can conflict with each other. Most } \\
\text { companies are unsuccessful in competing with two } \\
\text { business models simultaneously. }\end{array}$ & $\begin{array}{l}\text { Multiple } \\
\text { case studies }\end{array}$ \\
\hline Sabatier et al. (2010) & $\begin{array}{l}\text { Business model } \\
\text { portfolio }\end{array}$ & $\begin{array}{l}\text { "The range of different ways a firm delivers value to its } \\
\text { customers to ensure both its medium term viability and } \\
\text { future development." (p.432) A business model } \\
\text { portfolio enables companies to balance risks through } \\
\text { diversification. }\end{array}$ & $\begin{array}{l}\text { "If business models can be analogised as recipes, the } \\
\text { business model portfolio is the dinner-the } \\
\text { combination of contrasting dishes the host assembles } \\
\text { for the guests." (p.434) }\end{array}$ & $\begin{array}{l}\text { Four case } \\
\text { studies } \\
\text { (biotech } \\
\text { industry) }\end{array}$ \\
\hline $\begin{array}{l}\text { Snihur and Tarzijan } \\
\text { (2017) }\end{array}$ & $\begin{array}{l}\text { Multi-business } \\
\text {-model } \\
\text { organization }\end{array}$ & $\begin{array}{l}\text { An autonomous portfolio has no interdependencies } \\
\text { between the different business models of the same } \\
\text { organization (i.e. within complexity). } \\
\text { An integrated portfolio has interdependencies between } \\
\text { activities and partners of different business models (i.e. } \\
\text { between complexity). }\end{array}$ & $\begin{array}{l}\text { To limit the increase of between complexity, firms } \\
\text { should share and redeploy activities and partners } \\
\text { across the integrated business model portfolio. }\end{array}$ & $\begin{array}{l}\text { Single case } \\
\text { study (LAN } \\
\text { Airline) }\end{array}$ \\
\hline Sohl and Vroom (2017) & $\begin{array}{l}\text { Business model } \\
\text { relatedness }\end{array}$ & $\begin{array}{l}\text { A business model is conceptualized as a new way of } \\
\text { thinking about diversification (in contrast with } \\
\text { geographical and product diversification). }\end{array}$ & $\begin{array}{l}\text { Related business model diversification consists of } \\
\text { sharing inputs, resources, and exchange partners so } \\
\text { that the new and existing business activities are similar } \\
\text { and the firm improves performance. } \\
\text { Unrelated business model diversification is when the } \\
\text { new and existing business activities have little in } \\
\text { common; as such, they can even conflict with one } \\
\text { another, and performance is harmed. }\end{array}$ & Conceptual \\
\hline
\end{tabular}


within related business models improves firm performance (Sohl and Vroom, 2017). That is, a firm can address several customer segments with distinct business models, but "integrated business model portfolios" (Snihur and Tarzijan, 2017: 51) still "operate in tandem," (Casadesus-Masanell and Tarzijan, 2012: 132) with a certain complementarity and interdependency, to make more efficient use of resources, develop new income streams, and build sustainable competitive advantage.

This brief overview of the concepts of business model portfolio and business model diversification demonstrates that firms can maximize their existing resources and become more successful by operating distinct and yet complementary business models. However, there is a lack of research on the mechanisms behind P2P platforms' successful diversification into a portoflio of business models, as no sharing economy "pure-player" (Muzellec et al., 2015) operating multiple business models simultaneously has been studied to shed light on the particular resources or capabilities that enable growth and profits.

\section{Methodology}

The sharing economy is a new phenomenon. In this context, business model portfolios employed as a diversification strategy are also new, and previous research has failed to empirically investigate the "how and why" of these compounded phenomena. For this reason, case study research is a suitable approach, as it allows us to empirically examine such contemporary complex phenomenon in a real-life context (i.e. business model diversification in the shared mobility sector), particularly when the boundaries between the phenomenon and the context are not so clear (Yin, 2018). Case study research is well suited to illuminate why and how decisions were made and implemented, as well as their results, providing indepth information and thick descriptions on processes and outcomes, and highlighting their unique aspects (Eisenhardt and Graebner, 2007; Stake, 2005; Yin, 2018). Moreover, case study research has proved to yield valuable insights in organisational and management studies: previous research on business model diversification has typically been based on single case studies (e.g., Aversa and Haefliger, 2016; Casadesus-Masanell and Tarzijan, 2012; Snihu and Tarzijan, 2017).

In order to explain why and how sharing economy platform operators successfully diversify into a business model portfolio, we chose as unit of analysis the business model diversification process of GoMore (www.gomore.dk), a Danish shared mobility platform that is providing three different services: ridesharing, P2P car rental, and B2C leasing services. A single-case design (Yin, 2018) was chosen as GoMore constitutes a critical case to test Aversa et al.'s (2017) theoretical proposition that high-performing business model configurations maximize the existing resources of a firm and create hard-to-imitate capabilities, thereby generating growth and profit. GoMore is one of the few sharing economy platforms that currently operates more than two shared mobility business models at once, and, being founded more than a decade ago, it also offers the opportunity to investigate the startup survival through various stages of strategic business model diversification-in the tumultuous context of the sharing economy.

We adopted a longitudinal approach to data collection in order to understand the evolution of GoMore's business model(s) over time and capture the business model diversification process. ${ }^{2}$ Data

\footnotetext{
${ }^{2}$ Longitudinal research allows researchers to examine the dynamic nature of a focal construct of interest by collecting repeated measures over time from the same units of observations (e.g., individuals, organizations; Ployhart and Vandenberg, 2010).
}

collection was performed between January 2015 and January 2018 by one of the authors and constituted of semi-structured interviews (cf. Fontana and Frey, 2000) with six key informants from the platform management team (Table 2) and a document analysis of corporate presentations, communication materials (i.e. press releases and social media channels), internal survey data, website pages, and blog posts, as well as secondhand interview data (Table 3). The semi-structured interviews were thought of as extensions of ordinary conversations but were carried out with the aid of interview guides: questions were kept open and flexible to inspire respondents to elaborate on their experience without any restraints, which also allows new and interesting insights to be pursued (Fontana and Frey, 2000; Kvale, 1994). In particular, a first round of elaborated interviews taking a broad scope on events and processes (Rubin and Rubin, 2005) were conducted shortly after GoMore launched its car rental and leasing services in early 2015, while follow-up interviews were conducted in 2017-2018.

The management team also provided additional data (i.e. survey reports, founding history, and a promotional case study) that were combined with the rest of the collected documents, which were publicly available online or to registered platform members (Table 3). Together with the interview material, these documents provided additional historical data necessary to track GoMore's business model diversification process over time-for example, the elaboration of the tables and figures presented in Section 4. Employing multiple methods of inquiry and different sources of data was useful to validate, corroborate, and "triangulate" our interpretations of the case study, which increases the trustworthiness and validity of our results (Stake, 2005; Yin, 2018).

The documents and the transcribed interviews were analyzed through thematic content analysis, using a combination of deductive and inductive coding. The former included codes such as "value creation," "value delivery," "value capture," "resources," and "capabilities," while the latter included codes such as "customer segments," "acquisitions," and "partnerships." The identified codes were later recursively read in relation to one another so that patterns in the overall material could be discerned (Strauss and Corbin, 1990; Yin, 2018).

Finally, we conducted a systematic business model analysis of GoMore based on Baden-Fuller and Haefliger's (2013) framework (Table 4) and examined its business model portfolio using Aversa et al.'s (2017) visualization tool (Fig. 3). The latter makes it possible to identify and analyze the shared resources and capabilities that reduce costs (i.e. economies of scope by eliminating redundancy and better utilizing capacity) and enhance differentiation (i.e. reducing risk in uncertain environments) through complementarities within a business model portfolio, thereby resulting in enhanced performance, and unique and hard-to-imitate competitive advantage.

\section{Results}

GoMore is a Danish shared mobility platform with two million members internationally (800,000 in Scandinavia) and more than 50 employees. Since its business model diversification, it has grown to a great extent: between 2015 and 2017 the platform quadrupled its global membership base and doubled its staff (e.g., Denmark: from 15 to 31 employees), while the gross profit margin increased by $175 \%$ (from $M €-0.5$ to 0.4 for the Danish holding company). This section presents the evolution of GoMore from 2005 to 2018 (Fig. 2) and the introduction of its different business models to eventually constitute a business model portfolio (Table 4).

\subsection{Ridesharing}

GoMore was founded in 2005 in Denmark as a non-profit 
Table 2

Interviewees.

\begin{tabular}{|c|c|c|c|}
\hline Position and experience & Headquarters & Interview date & Length of interview \\
\hline Chief Marketing Officer (since April 2014)a & Denmark & January 2015 & $60 \mathrm{~min}$. \\
\hline Community Manager Sweden (since May 2014) & Denmark & January 2015 & $60 \mathrm{~min}$. \\
\hline Market Manager Sweden (since June 2014) ${ }^{\mathrm{a}}$ & Denmark & January 2015 & $60 \mathrm{~min}$. \\
\hline Customer Experience Manager Norway \& Sweden (since January 2017) & Denmark & August 2017 & Email \\
\hline Talent Acquisition and Development Manager France (since February 2017) & France & August 2017 & Email \\
\hline Market Manager Norway \& Sweden (since June 2015) ${ }^{\mathrm{a}}$ & Denmark & January 2018 & $30 \mathrm{~min}$. \\
\hline
\end{tabular}

a Senior management.

Table 3

Document analysis.

\begin{tabular}{|c|c|c|}
\hline Document & Description & Size \\
\hline Blog posts & $\begin{array}{l}\text { Blog entries from the communication team about reaching milestones, product launch, usage tips, and community engagement ( } 41 \% \text { in } \\
\text { French, 52\% in Nordic languages, } 7 \% \text { in Spanish) since } 2013 \text {. }\end{array}$ & $\begin{array}{l}848 \\
\text { pages }\end{array}$ \\
\hline Email campaigns & Communication material related to community engagement. & $\begin{array}{l}172 \\
\text { pages }\end{array}$ \\
\hline $\begin{array}{l}\text { Q\&A website } \\
\text { section }\end{array}$ & $\begin{array}{l}\text { Customer support and knowledge base about ridesharing, P2P car rental, and B2C leasing services via the platform, as well as community } \\
\text { guidelines. }\end{array}$ & $\begin{array}{l}130 \\
\text { pages }\end{array}$ \\
\hline Press releases & Official public announcements (i.e. funding rounds, acquisitions, and partnerships) since 2015. & 40 pages \\
\hline Survey reports & Reports from management and secondary studies. & 29 pages \\
\hline News articles & Successes and failures (critiques), mostly covered by the Danish, Swedish, and French press and opinion articles. & 14 pages \\
\hline $\begin{array}{l}\text { Promotional case } \\
\text { study }\end{array}$ & History and data used in presentations. & 4 pages \\
\hline Videos & $\begin{array}{l}\text { Presentations of the market strategy and back-end processes (to investors, workshop participants, or conference attendees), as well as ads, } \\
\text { secondhand interviews, and reportages. }\end{array}$ & $200 \mathrm{~min}$. \\
\hline Social media & Engagement data from Facebook pages (Sep. 2014-Feb. 2015). & \\
\hline
\end{tabular}

Table 4

GoMore's business models.

\begin{tabular}{|c|c|c|c|c|}
\hline & $\begin{array}{l}\text { Customer identification (customer } \\
\text { groups) }\end{array}$ & Customer engagement (value propositions) & $\begin{array}{l}\text { Value chain linkages (network } \\
\text { of actors) }\end{array}$ & Monetization mechanisms (pricing) \\
\hline Ridesharing & $\begin{array}{l}\text { Peer providers: car owners, } \\
\text { consumers of P2P car rental, or } \\
\text { consumers of B2C leasing. } \\
\text { Consumers: passengers. }\end{array}$ & $\begin{array}{l}\text { Providers are offered to share their traveling } \\
\text { costs. } \\
\text { Consumers are offered a low-cost, social, and } \\
\text { environmentally-friendly mobility solution. }\end{array}$ & $\begin{array}{l}\text { One online payment partner } \\
\text { Three insurance partners } \\
\text { (Scandinavia } \neq \text { France } \neq \\
\text { Spain) }\end{array}$ & $\begin{array}{l}\text { Consumers pay a } 12.5 \% \text { commission } \\
\text { fee (except in France, where it is free } \\
\text { of charge). }\end{array}$ \\
\hline $\begin{array}{l}\text { P2P car } \\
\text { rental }\end{array}$ & $\begin{array}{l}\text { Peer providers: car owners or } \\
\text { consumers of } \mathrm{B} 2 \mathrm{C} \text { leasing. } \\
\text { Consumers: individuals who need a } \\
\text { car. }\end{array}$ & $\begin{array}{l}\text { Providers are offered to compensate } \\
\text { ownership costs by finding others to rent their } \\
\text { car to when not in use. } \\
\text { Consumers are offered rental cars at a } \\
\text { competitive price. }\end{array}$ & $\begin{array}{l}\text { One online payment partner } \\
\text { Three insurance partners } \\
\text { (Scandinavia } \neq \text { France } \neq \\
\text { Spain) }\end{array}$ & $\begin{array}{l}\text { Providers pay a } 20.5 \% \text { commission } \\
\text { fee. } \\
\text { Consumers pay insurance extras. }\end{array}$ \\
\hline B2C leasing & $\begin{array}{l}\text { Consumers: individuals who need a } \\
\text { car. }\end{array}$ & $\begin{array}{l}\text { Consumers are offered a car subscription to } \\
\text { replace car ownership and to finance it through } \\
\text { P2P car rental. }\end{array}$ & $\begin{array}{l}\text { One or more leasing partners } \\
\text { per region (Scandinavia } \neq \\
\text { France \& Spain) }\end{array}$ & $\begin{array}{l}\text { Commission }(\approx 5 \%) \text { on partner's } \\
\text { contract. }\end{array}$ \\
\hline
\end{tabular}

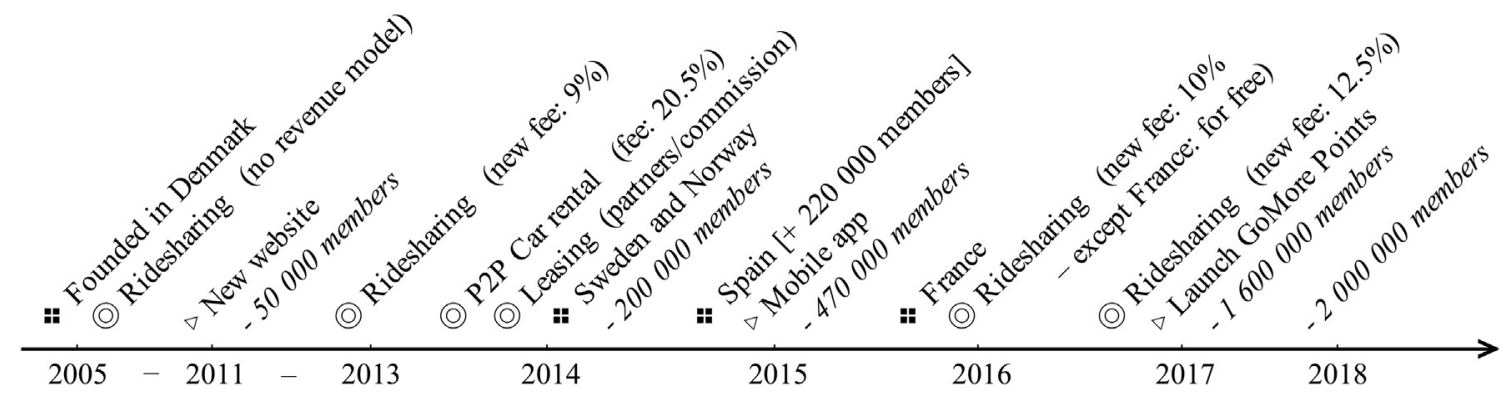

Fig. 2. GoMore's timeline. Note: ๑ indicates business model diversification or modifications; $\$$ indicates geographical expansion.

website for ridesharing: its online bulletin board aimed to make it more convenient for passengers and drivers to find each other. By 2011, when the founders realized the platform's commercial opportunity, there were 50.000 registered members engaged through word-of-mouth. GoMore became a for-profit organization and received financial support from private investors and venture capital to enhance the matchmaking platform with technological developments, such as peer ratings, cashless transactions (in partnership with a Scandinavian online payment solutions firm), and internal messaging. GoMore also partnered with gas stations to 


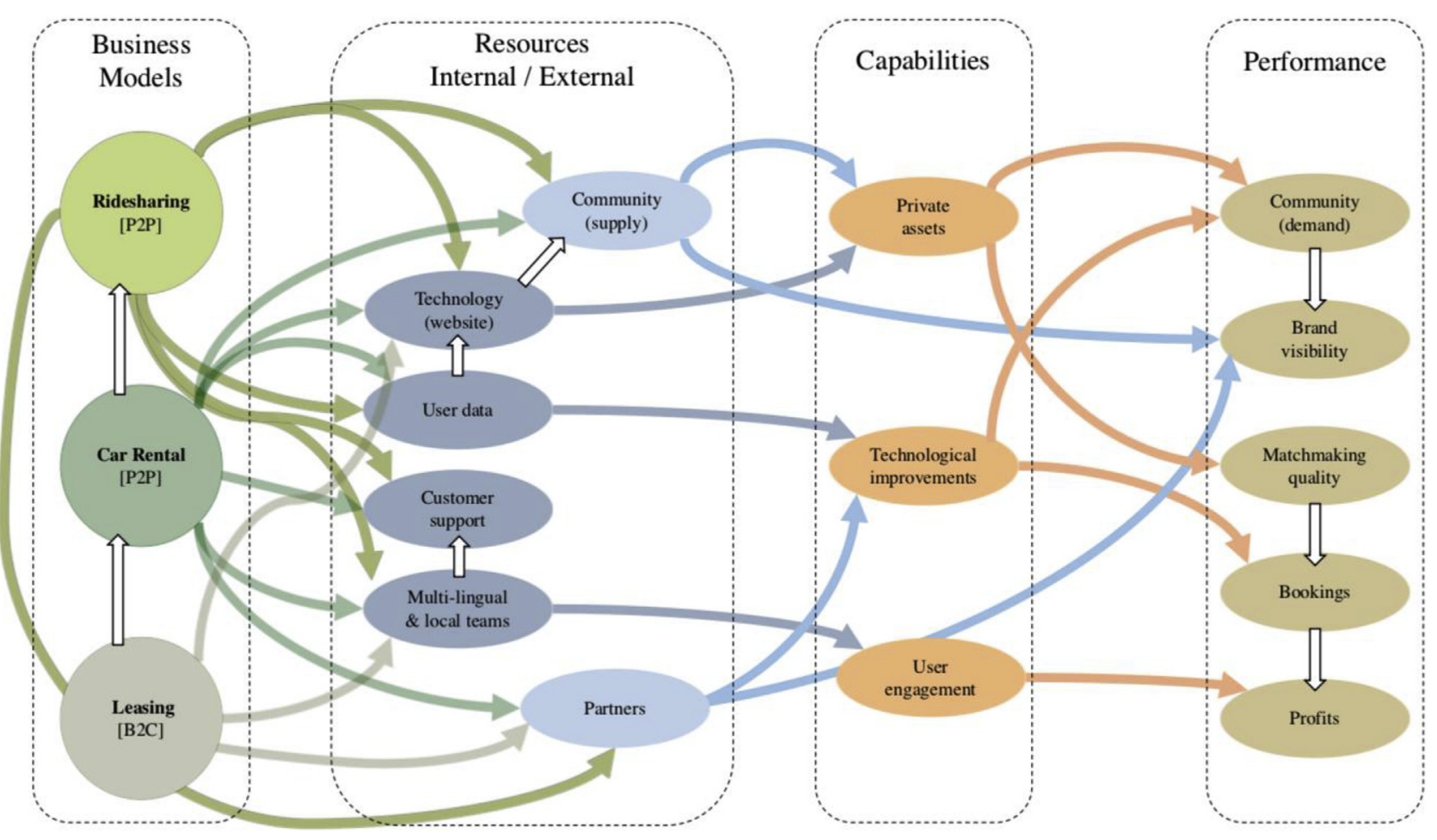

Fig. 3. GoMore's business model portfolio.

offer free coffee to ridesharing participants and with Copenhagen airport to allocate dedicated parking space for ridesharing coordination. In 2013, GoMore switched from being a free ridesharing website to charging a fee for each facilitated P2P transaction, thereby establishing its ridesharing business model. Initially, the fee-based revenue model (paid by the consumers for each seat) consisted of a fixed reservation fee (approximately $€ 0.30$ ) plus $9 \%$ of the seat price, which was raised to $10 \%$ in 2016 and $12.5 \%$ in $2018 .^{3}$ With additional private equity funding, the team launched their customer support service and further integrated technological developments into the platform to offer additional convenience and improve the matchmaking quality. By capitalizing on its community of "hitchhikers 2.0," GoMore started to aggregate a growing crowd of consumers with diverse mobility needs. However, the platform's main problem was that there were more passengers looking for a ride than drivers with empty car seats. That is, the demand for shared mobility was greater than the available supply-a situation that GoMore saw as an opportunity to grow further.

\subsection{Peer-to-peer car rental}

In February 2014, in order to increase the number of available rides on the platform, GoMore launched a P2P car rental service that enabled the existing community of drivers (peer providers) to offer their cars to other platform users (consumers): "People get the experience of renting a friend's car instead of hiring a car. It's a business transaction, but they talk about it as if they do each other a favor" (Senior Manager). The partner insurance firm covered the

\footnotetext{
${ }^{3}$ GoMore recently announced a new revenue model for ridesharing in Denmark based on a fixed fee of $€ 2$ per reservation and a $5 \%$ commission based on the seat price minus the fixed fee (13 November 2018). In other words, the platform is trying a new model to increase revenues from ridesharing.
}

rental period (e.g., damage, third party, and roadside assistance), and GoMore integrated a validation system requiring a license number and driving experience into the process of becoming a member. Additionally, GoMore developed a mobile app that allowed GPS localization of car rentals to provide additional convenience. Consumers of GoMore services seemed satisfied "with the rapidity, without paperwork, with the flexibility of the pick-up location, and a lower price; we're doing the same thing as Hertz, just cheaper" (Senior Manager). GoMore charges peer providers a $20.5 \%$ fee to cover administration and insurance costs. With this second business model focusing on P2P car rental, GoMore was able to serve consumers with greater mobility needs (e.g., longer journeys and more flexibility) on the one hand, and car owners were able to finance their costs on the other hand. The platform replicated the same matchmaking-based revenue model of its ridesharing service, but it targeted a different customer segment. As of 2017, there were 20,000 car rentals available on GoMore.

The P2P car rental business model was meant to provide additional supply for the platform's ridesharing services (i.e. car rental users could further take advantage of the platform to offer empty seats on their journeys as peer providers of ridesharing services). However, "a lot of consumers were actually promised something that [GoMore was] not really delivering" (Senior Manager) because there were not enough peer providers offering their car on the platform. Demand for accessing a car on a short-term basis was higher than the available supply of private cars-a problem that the introduction of GoMore's B2C leasing services intended to solve.

\subsection{Business-to-consumer leasing}

In September 2014, GoMore announced its partnership with a fleet management firm to offer leasing services of modern cars with low emissions and electric engines. Since then, GoMore partnered with various leasing firms and experimented with different leasing contracts: "new car leasing" (i.e. regular leasing for 12-36 months), 
“economic leasing" (36-60 months with buying option), "shortterm leasing" (1-4 months), and "reused car leasing" (i.e. by a previous customer). GoMore's revenue model differs depending on the partner and the contract duration: on average the platform charges a 5\% commission fee on contracts. Consumers of GoMore's leasing service could also enjoy the full benefits of car ownership at a reduced cost by becoming peer providers of P2P car rentals when the car is idle-or listing their empty seats (ridesharing) on the platform: "This sort of car subscription is for people who need to own a car but for whom 'sharing is natural,' and they have adopted the movement away from ownership, so we propose them a price scenario where leasing costs are shared via ridesharing and [P2P car] rental" (Senior Manager). GoMore claims that 50\% of leasing contractors use the platform's rental services to compensate their costs. As such, GoMore's B2C leasing model provides additional supply to its two other P2P services. Each new mobility service subsequently introduced by the firm thus aimed at increasing the supply of the already existing matchmaking business models. This strategy enabled GoMore to be competitive in several markets: "The combination is what makes us unique-an all-in-one platform" (Senior Manager).

In the future, GoMore might further diversify its business model portfolio by adding another matchmaking service to its existing platform. For instance, in 2015 the management team considered offering also delivery services as people were booking seats for their packages: "Our competitive advantage over traditional delivery companies is our flexibility" (Senior Manager). However, this idea has not been pursued any further.

\subsection{Customer acquisition and geographic expansion}

GoMore's value propositions aim to offer financial compensation for car ownership and travel costs to peer providers "by getting more out of a car" and offering "flexible, affordable, and green transportation" to consumers with diverse access needs. The platform management team was confident that, overall, the platform has a superior value proposition by offering a combination of three mobility services, which competing platforms are currently not able to provide. In addition to targeting different customer segments through different business models, GoMore also encourages consumers to use multiple mobility services. In 2017, the platform soft launched a loyalty reward system: "GoMore Points are used to push people through business models" (Senior Manager). Loyalty points can be redeemed by a member of one mobility service for a more advanced service-for example, points acquired through a rideshare unlock a discount on P2P car rentals. Despite GoMore's continuous marketing efforts to recruit peer providers (supply), the platform continues to attract more consumers (demand), thereby challenging the successful operation of its business model portfolio. Moreover, the small number of peer reviews on the platform seem to indicate that consumers' sign-ups are not necessarily translating into actual bookings. Ultimately, the launch of GoMore Points shows that only few customers use different services (e.g., lease contractors may offer P2P car rentals but not share rides).

In addition to business model diversification, GoMore has also been intensifying its efforts to expand geographically since 2014 . Due to geographical and cultural proximity, the Danish team first targeted other Scandinavian countries in the summer of 2014. Following a large investment from venture capitalists, GoMore acquired Amovens and its team in Spain in early 2015. Amovens-a ridesharing platform founded in 2009 with 220,000 registered members-kept its original name after the acquisition, and it remained free of charge for its customers until 2016. Peer-to-peer car rental and leasing services were introduced in these markets by the end of 2015. GoMore also considered entering the German and British markets but eventually decided to focus on France, where it started to operate in early 2016. Nevertheless, the geographical expansion of GoMore, based on the replication of its business model portfolio through the establishment of new subsidiary companies and the acquisition of established platforms, has been limited due to a lack of sufficient financial liquidity. In other words, GoMore seems to not have been able to convince investors of the long-term viability of its strategy (cf. Appendix).

\section{Discussion}

GoMore has infused technological developments into its initial bulletin board website for ridesharing, and the platform diversified into multiple business models to address different customer segments and increase its hold onto the dynamic shared mobility sector. As a result, the GoMore platform provides a "one-stop-shop carsharing solution" by means of a portfolio of three distinct business models with strategic connections between them. The business model diversification not only allowed GoMore to address different customer segments, but it aimed at increasing the supply of peer providers in the P2P market(s): for example, consumers who get access to a car through $\mathrm{B} 2 \mathrm{C}$ leasing or P2P car rental become potential peer providers for ridesharing. None of GoMore's business model is unique, as competitors also offer services to solve mobility needs with a car as the main resource (Chan and Shaheen, 2012; Cohen and Kietzmann, 2014; Furuhata et al., 2013; Guyader, 2018; Münzel et al., 2017; Schaefers, 2013; Shaheen et al., 2012, 2016; Wilhelms et al., 2017). However, GoMore's competitive advantage lies in its diversification into three business models that complement each other to maximize car usage efficiency and increase the offer of available mobility services.

In order to analyze the connections and complementarities across multiple business models, GoMore's business model portfolio is depicted in Fig. 3 using Aversa et al.'s (2017) visualization tool. GoMore's business models appear to be synergistic rather than in competition with one another. By sharing resources and capabilities, GoMore achieves cost savings, reduces risk, improves performance, and sustains its competitive advantage, thus supporting previous studies on the advantages of deploying a business model portfolio (e.g., Aversa et al., 2017; Casadesus-Masanell and Tarziján, 2012; Sabatier et al., 2010; Snihur and Tarziján, 2017; Sohl and Vroom, 2017). In particular, the shared mobility platform relies on six key resources (member community, platform technology, user data, customer support, local management teams, and partners), three key capabilities (leverage of the community's assets, technological improvement, and user engagement), and five performance measures (new members, brand visibility, matchmaking quality, bookings, and profits).

\subsection{Resources}

Both P2P business models (i.e. ridesharing and car rental) rely on the complete range of GoMore's key resources, both internal and external. First, the most important internal resource is the actual website, which has hosted the online platform since 2005, and, in particular, the proprietary technology (e.g., the matchmaking algorithm and booking management) embedded in the website and mobile app. GoMore has improved its product (i.e. the online platform) over time to more effectively facilitate P2P transactions, striving to build a functional, trustworthy, and cost-efficient solution. Additionally, the user data collected from each profile and behavior on the platform is further used to not only match demand with supply through the platform algorithm, but also to segment customers and customize marketing communication. Another internal resource is the customer support provided through a rich 
frequently asked questions website section and a call center, which assists GoMore members in using the online platform and with other practical issues (e.g., insurance coverage or the best location to meet up for ridesharing). Eventually, GoMore benefits from multi-lingual and local management teams, which were recruited or acquired in each regional market (i.e. Scandinavia, Spain, and France) to be able to better interact with local partners, to understand and adapt to local needs, and to compete with different pricing strategies depending on local market competition.

Second, one of the external resources extensively used by GoMore in ridesharing and P2P car rentals is the community of registered members. Over time, a number of individuals registered on the platform with the intention of participating in shared mobility, which GoMore leverages by engaging them as peer providers in exchange for monetary compensation. For example, ridesharing participants are reminded through communication messages about the economic benefits of offering their car for rental. Retaining peer suppliers (not only attracting new consumers) is critical for sharing economy business models (Kumar et al., 2018). Furthermore, all three business models use partners as external resources. Key partnerships were established to facilitate or enable shared mobility services: online payment, gas stations, public infrastructures, insurance, and leasing firms. Sharing networks and redeploying partners are useful for achieving economies of scale (Casadesus-Masanell and Tarziján, 2012; Snihur and Tarziján, 2017; Sohl and Vroom, 2017). In line with studies on twosided platforms (Einav et al., 2016; Evans and Schmalensee, 2010; Muzellec et al., 2015), GoMore focuses on building the supply side of the P2P market in order to reach a critical mass of users. The financial incentive is emphasized to help peer providers compensate their car ownership or travel costs.

\subsection{Capabilities}

There are three key capabilities from which GoMore can establish competitive advantage. The first is the underutilized capacity of assets owned by the community of registered members (i.e. empty seats and idle cars). As a sharing economy pure player, GoMore does not own any cars, but it takes advantage of drivers willing to take passengers in their car and owners willing to let borrowers use their car. Another related capability is GoMore's technological improvements-such as an effective matchmaking algorithm, the integration of an identity validation process, a mobile app, and the facilitation of online payments-which have been critical for further developing P2P activities, notably in establishing trust between parties. Information and communications technology (ICT) has been shown to facilitate platform development in the sharing economy (e.g., Belk, 2014; Benoit et al., 2017; Perren and Kozinets, 2018), but it is an understanding of network effects that is central to platform strategy (Van Alstyne et al., 2016). Finally, community engagement is an important capability that GoMore fosters with its social network presence and by encouraging users to recommend the platform to acquaintances. Moreover, the GoMore points system is an example of how members are stimulated to use multiple mobility services offered by the platform, as well as being a loyalty program aimed at retaining customers.

\subsection{Performance}

GoMore founders celebrated the 13th anniversary of their platform in 2018-seven years of which were as a for-profit organization. The start-up has survived in the tumultuous and competitive shared mobility sector, whereas other platforms went out of business (e.g., because of a lack of financing, a failure to reach a critical mass of users, and/or a flawed business model). Now,
GoMore is the largest shared mobility platform in Scandinavia in terms of the number of community members, and it is the second largest in Europe that deploys more than one shared mobility business model at once (after BlaBlaCar). ${ }^{4}$ In addition to the key figures of online users (i.e. individuals who sign up on the website-which does not necessarily translate into usage), another important performance indicator is brand visibility, which GoMore improved through word-of-mouth from its new and existing member base (i.e. through community engagement), as well as through branded communication from its network of partners.

One more performance measure is the matchmaking quality provided by the platform, which increases with the synergy across multiple P2P markets that is facilitated by the business model portfolio. The greater the community (i.e. registered members), the more assets (i.e. empty seats or underutilized cars) can be leveraged and offered through the platform to increase the likelihood of finding a match (i.e. supply) that is able to satisfy the specific access needs of a customer segment. Vice versa, the larger the community, the more potential passengers/renters are aggregated through the platform to increase the likelihood of finding a match between demand and mobility services offered by peer providers seeking to compensate their costs. With continuous technological improvements and a higher matchmaking quality, more activity and traffic is registered on the platform to organize ridesharing and P2P car rentals, and a greater number of transactions between peer providers and consumers are facilitated (see website usage and app downloads in the Appendix).

Eventually, GoMore takes a commission on each P2P transaction, as well as on leasing contracts, so profits increase by having members who are engaged to take full advantage of the opportunities offered by the "all-in-one" platform and use more than one shared mobility service. GoMore's revenue model is based on service fees when the car is used through the platform: $12.5 \%$ on ridesharing, $20.5 \%$ on $\mathrm{P} 2 \mathrm{P}$ car rentals, and a commission on $\mathrm{B} 2 \mathrm{C}$ leasing contracts. Currently, the ridesharing service is provided for free in France to compete with BlaBlaCar, ${ }^{5}$ while profits are drawn from the other two business models. That is, GoMore's main revenue streams are now generated from P2P car rentals despite having debuted as a ridesharing platform.

To further evaluate GoMore's success, performance measures can be used to compare the platform with its direct competitors (Appendix). Despite being the market leader in Scandinavia and the first to diversify into more than one business model in the shared mobility sector (in 2014), GoMore still has a lower number of cars available compared with its European competitors and it is far from catching up with the French international leader (i.e. Drivy). ${ }^{6}$ This may also be explained by the fact that competing platforms already existed when GoMore started to facilitate P2P car rentals.

\footnotetext{
4 Despite its strong global brand and a "unicorn" valuation, BlaBlaCar only recently added a leasing service (in 2016), which is available exclusively to experienced members ("ambassadors"). However, the launch of the BlaBlaLines app (in 2017) and the acquisition of carpooling platform Less (in 2018) seem to suggest a stronger focus of BlaBlaCar on its core ridesharing business model (Guyader, 2018).

${ }^{5}$ BlaBlaCar was highly criticized by the French ridesharing community when it switched "from free to fee" by instauring a platform business model.

${ }^{6}$ In France, GoMore competes with Drivy, (i.e. the largest P2P car rental platform in Western Europe in terms of available car rentals), OuiCar (i.e. the second most popular P2P car rental platform in France), and Koolicar (backed up by PSA Peugeot Citroen, which integrated it to its app Free2Move). However, none of them diversified into multiple shared mobility business models, and only Drivy recently sped up its geographical expansion in some neighboring countries. Moreover, Snappcar (i.e. the leading P2P car rental platform in the Netherlands) geographically expanded to Scandinavian markets (in 2015), but only recently diversified into B2C leasing services (in 2018) in Denmark—not Sweden.
} 


\section{Conclusion}

Sharing economy pure players that operate digital platforms are more agile than "brick-and-mortar businesses" (e.g., due to their inventory and maintenance costs of tangible goods and the necessary infrastructure) with regards to changing their business model (Baden-Fuller et al., 2017). By deploying key resources and capabilities into related business models, GoMore can offer complementary shared mobility services: ridesharing, P2P car rental, and B2C leasing. The three services optimize the overall value proposition of the shared mobility platform as a holistic solution for a variety of users and access needs. This is in line with the strategy literature that suggests the development of unique business models for each customer segment (Casadesus-Masanell and Tarziján, 2012; Sabatier et al., 2010).

\subsection{Theoretical contributions}

This paper contributes to the existing literature in three ways. First, we identify six key resources (member community, platform technology, user data, customer support, local management teams, and partners) and three key capabilities (leverage of the community's assets, technological improvement, and user engagement) to successfully operate a shared mobility business model portfolio. Our findings also provide empirical evidence that supports conceptual research by Benoit et al. (2017), which suggested that the necessary resources and capabilities of sharing economy platform providers are: 1) knowledge about peer providers and consumers (i.e. GoMore's user data and local teams), 2) a network of peer providers and consumers (i.e. GoMore's leverage of the community's assets), and 3) powerful stakeholders that can communicate the societal benefits (i.e. GoMore's partners and user engagement). In line with Belk (2014) and Benoit et al. (2017), we also find that the technological capabilities embedded in the online sharing platform and continuous ICT developments are key assets in facilitating P2P exchanges, and we further argue that customer support is a strategic resource to sustain competitive advantage over grassroots-led initiatives.

Second, we integrate the marketing literature on access-based consumption and the sharing economy with the strategy literature on business models. In particular, we demonstrate how the synergetic use of assets and activities across different business models is a strategic tool to achieve competitive advantage in the shared mobility market. Moreover, we provide insights regarding the business model diversification process of a sharing economy pure player (versus the merger and acquisition strategies adopted by incumbents such as Daimler and BMW $)^{7}$ and the rationale for adopting a business model portfolio in the sharing economy.

Third, we developed an in-depth case study of a shared mobility platform that deploys both B2C and P2P business models. The findings of this research advance current knowledge on the mechanisms behind successful P2P platforms, which is a still under-explored area of research (Benoit et al., 2017; Piscicelli et al., 2018; Vaskelainen and Piscicelli, 2018). Moreover, existing marketing studies in the context of the sharing economy have investigated separately B2C (commercial or "traditional") rental business models (e.g., Bardhi and Eckhardt, 2012; Lamberton and Rose, 2012; Schaefers et al., 2016) and P2P business models (e.g., Philip et al., 2015; Wilhelms et al., 2017; Zervas et al., 2017). By examining a firm that combines different business modesl based on B2C and PSS (i.e. leasing), as well as P2P interactions (i.e. ridesharing and P2P car

\footnotetext{
${ }^{7}$ See the press release "BMW Group and Daimler AG agree to combine mobility services" available at: http://media.daimler.com/marsMediaSite/ko/en/34636751/.
}

rental), this study offers original insights to better understand business model diversification in the sharing economy. Our findings corroborate Frenken's (2017: 8) thesis that "[business model] integration efforts provide consumers with maximum flexibility and variety of options while the platform acts as a 'one-stop-shop'."

\subsection{Managerial recommendations}

From this study, managers can understand that sharing economy platforms need to fuel the supply side of their P2P markets to capitalize on the unfulfilled demand for access-based consumption. For example, GoMore focuses its communication on the financial benefit of offering empty car seats through the platform in order to attract more potential drivers rather than passengers. Moreover, the GoMore case analysis shows that business model diversification needs to be pursued in complementary markets and services instead of competing ones. For example, GoMore does not provide ride-hailing services as that would cannibalize key resources from its other business models: owners would not have their car underutilized, since they would drive it to hail rides and earn money.

\subsection{Limitations and future research}

In this paper, we analyzed a shared mobility platform that is successfully operating a business model portfolio. However, the study was based on a single case and a limited number of interviews. As such, further research is needed to systematically analyze and compare additional case studies (Siggelkow, 2007; Stake, 2005; Yin, 2018), as well as to investigate other sectors of the sharing economy in order to advance our understanding of the business model diversification process. Another limitation is that, although GoMore has been successful so far, we do not know if the platform and its business model portfolio will remain successful or will change in the future. Finally, adopting a quantitative approach to examine business model portfolios could provide additional insights into the specific influence of different resources and capabilities on firm performance and success factors.

Future research on business model diversification could also focus on the role and management of ancillary services, such as car maintenance or insurance provision, in a portfolio of business models. Moreover, studies with a focus on the sharing economy could also investigate how networks of partners articulate in the shared mobility ecosystem and how industry incumbents can respond to the rise of the sharing economy. For example, Avis Budget Group acquired Zipcar to diversify its traditional car rental service towards a more access-based oriented consumer base (e.g., Fournier et al., 2013), and GoMore and Snappcar share the same leasing partners across markets. Daimler and BMW merging their carsharing, ride-hailing, parking, charging, and other operations into a "holistic ecosystem of intelligent, seamlessly connected mobility services, available at the tap of a finger" also suggests the need for additional research on such all-in-one portfolio of mobility services in a single mobile app. ${ }^{8}$

\section{Appendix A}

Supplementary data to this article can be found online at https://doi.org/10.1016/j.jclepro.2019.01.114.

\footnotetext{
${ }^{8}$ See also Deloitte's review on "The future of mobility" available at: https://www2. deloitte.com/insights/us/en/deloitte-review/issue-20.html/, and Drive Sweden's map of "Alliances between Automakers, Tech Companies and Mobility Start-ups" available at https://kumu.io/-/20766\#map-503QwKvy/.
} 


\section{References}

Aversa, P., Haefliger, S., 2016. Building Business Model Portfolios: Implications for Strategic Diversification. [working Paper] Cass Business School. City University of London, London, UK.

Aversa, P., Haefliger, S., Reza, D.G., 2017. Building a winning business model portfolio. MIT Sloan Manag. Rev. 58 (4), 47-54.

Baden-Fuller, C., Giudici, A., Haefliger, S., Morgan, M.S., 2017. Business models and value: analytical comparisons of scalable solutions and digital platforms. In: Acad. Manag. Proc. (Academy of Management Annual Meeting 2017, Atlanta, $\mathrm{GA}$.

Baden-Fuller, C., Haefliger, S., 2013. Business models and technological innovation. Long. Range Plan. 46 (6), 419-426.

Bardhi, F., Eckhardt, G.M., 2012. Access-based consumption: the case of car sharing J. Consum. Res. 39 (4), 881-898.

Belk, R.W., 2014. Sharing versus pseudo-sharing in web 2.0. Anthropol. 18 (1), 7-23.

Benoit, S., Baker, T.L., Bolton, R.N., Gruber, T., Kandampully, J., 2017. A triadic framework for collaborative consumption: motives, activities and resources \& capabilities of actors. J. Bus. Res. 79, 219-227.

Botsman, R., Rogers, R., 2010. What's Mine Is Yours: the Rise of Collaborative Consumption. HarperCollins, London.

Casadesus-Masanell, R., Ricart, J.E., 2010. From strategy to business models and onto tactics. Long. Range Plan. 43 (2-3), 195-215.

Casadesus-Masanell, R., Tarzijan, J., 2012. When one business model isn't enough. Harv. Bus. Rev. 90 (January/February).

Chan, N., Shaheen, S., 2012. Ridesharing in north America: past, present, and future. Trans. Rev. 32 (1), 93-112.

Cohen, B., Kietzmann, J., 2014. Ride on! Mobility business models for the sharing economy. Organ. Environ. 27 (3), 279-296.

Eckhardt, G.M., Bardhi, F., 2015. The sharing economy isn't about sharing at all. Harv. Bus. Rev. 39 (4), 881-898.

Einav, L., Farronato, C., Levin, J., 2016. Peer-to-peer markets. Annu. Rev. Econom. 8, 615-635.

Eisenhardt, K.M., Graebner, M.E., 2007. Theory building from cases: opportunities and challenges. Acad. Manag. J. 50 (1), 25-32.

Evans, D.S., Schmalensee, R., 2010. Failure to launch: critical mass in platform businesses. Rev. Netw. Econ. 9 (4).

Fournier, S., Eckhardt, G.M., Bardhi, F., 2013. Learning to play in the new "share economy". Harv, Bus, Rev, 91 (July-August).

Frenken, K., 2017. Political economies and environmental futures for the sharing economy. Philos. Trans. R. Soc. A: Math. Phys. Eng. Sci. 375, 2-15.

Fontana, A., Frey, J.H., 2000. The interview: from structured questions to negotiated text. In: Denzin, Lincoln (Eds.), Handbook of Qualitative Research, second ed. Sage, Thousand Oaks, CA, pp. 645-672.

Furuhata, M., Dessouky, M., Ordóñez, F., Brunet, M.-E., Wang, X., et al., 2013. Ridesharing: the state-of-the-art and future directions. Transp. Res. Part B Methodol. 57 (11), 28-46.

Guyader, H., 2018. No one rides for free! Three styles of collaborative consumption. J. Serv. Market. 32 (6), 692-714.

Hamari, J., Sjöklint, M., Ukkonen, A., 2016. The sharing economy: why people participate in collaborative consumption. J. Assoc. Inf. Sci. Technol. 67 (9), 2047-2059.

Johnson, M., Herrmann, A., Huber, F., 1998. Growth through product-sharing services. J. Serv. Res. 2 (1), 167-177.

Kirchherr, J., Piscicelli, L., Bour, R., Kostense-Smit, E., Muller, J., HuibrechtseTruijens, A., Hekkert, M., 2018. Barriers to the circular economy: evidence from the European Union (EU). Ecol. Econ. 150, 264-272.

Kumar, V.K., Lahiri, A., Dogan, O.B., 2018. A strategic framework for a profitable business model in the sharing economy. Ind. Market. Manag. 69, 147-160.

Kvale, S., 1994. Ten standard objections to qualitative research interviews. J. Phenomenol. Psychol. 25 (2), 147-173.

Lamberton, C.P., Rose, R.L., 2012. When is ours better than mine? A framework for understanding and sharing systems. J. Mark. 76 (4), 109-125.

Lovelock, C., Gummesson, E., 2004. Whither services marketing? In search of a new paradigm and fresh perspectives. J. Serv. Res. 7 (1), 20-41.

Markides, C., 2013. Business model innovation: what can the ambidexterity literature teach US? Acad. Manag. Perspect. 27 (4), 313-323.

Markides, C., Charitou, C.D., 2004. Competing with dual business models: a contingency approach. Acad. Manag. Exec. 18 (3), 22-36.

Markides, C., Oyon, D., 2010. What to do against disruptive business models (when and how to play two games at once). MIT Sloan Manag. Rev. 51 (4), 25-32.

Martin, C.J., Upham, P., 2016. Grassroots social innovation and the mobilisation of values in collaborative consumption: a conceptual model. J. Clean. Prod. 134, 204-213.

Massa, L., Tucci, C.L., Afuah, A., 2017. A critical assessment of business model research. Acad. Manag. Ann. 11 (1), 73-104.

Moeller, S., Wittkowski, K., 2010. The burdens of ownership: reasons for preferring renting. Manag. Serv. Qual. 20 (2), 176-191.

Mont, O., 2002. Clarifying the concept of product-service system. J. Clean. Prod. 10 (3), 237-245.

Münzel, K., Boon, W., Frenken, K., Vaskelainen, T., 2017. Carsharing business models in Germany: characteristics, success and future prospects. Inf. Syst. e-Bus. Manag. 1-21.

Muzellec, L., Ronteau, S., Lambkin, M., 2015. Two-sided Internet platforms: a business model lifecycle perspective. Ind. Market. Manag. 45 (1), 139-150.

Owyang, J., 2016. Honeycomb 3.0: the collaborative economy market expansion. web-strategist.com. Available at: http://www.web-strategist.com/blog/2016/ 03/10/honeycomb-3-0-the-collaborative-economy-market-expansion-sxsw/. (Accessed 29 January 2018).

Peck, J., Shu, S.B., 2018. Psychological Ownership and Consumer Behavior. Springer, Chicago.

Philip, H.E., Ozanne, L.K., Ballantine, P.W., 2015. Examining temporary disposition and acquisition in peer-to-peer renting. J. Market. Manag. 31 (11-12), 1310-1332.

Piscicelli, L., Cooper, T., Fisher, T., 2015. The role of values in collaborative consumption: insights from a product-service system for lending and borrowing in the UK. J. Clean. Prod. 97, 21-29.

Piscicelli, L., Ludden, G.D.S., Cooper, T., 2018. What makes a sustainable business model successful? An empirical comparison of two peer-to-peer goods-sharing platforms. J. Clean. Prod. 172, 4580-4591.

Perren, R., Kozinets, R.V., 2018. Lateral exchange markets: how social platforms operate in a networked economy. J. Mark. 82 (1), 20-36.

Ployhart, R.E., Vandenberg, R.J., 2010. Longitudinal research: the theory, design, and analysis of change. J. Manag. 36, 94-120.

Reim, W., Parida, V., Örtqvist, D., 2015. Product-Service Systems (PSS) business models and tactics - a systematic literature review. J. Clean. Prod. 97, 61-75.

Rubin, H.J., Rubin, I., 2005. Qualitative Interviewing: the Art of Hearing Data. Sage Publications, London.

Sabatier, V., Mangematin, V., Rousselle, T., 2010. From recipe to dinner: business model portfolios in the european biopharmaceutical industry. Long. Range Plan. 43 (2-3), 431-447.

Schaefers, T., 2013. Exploring carsharing usage motives: a hierarchical means-end chain analysis. Transp. Res. Part A Policy Pract. 47, 69-77.

Schaefers, T., Wittkowski, K., Benoit, S., Ferraro, R., 2016a. Contagious effects of customer misbehavior in access-based services. J. Serv. Res. 19 (1), 3-21.

Shaheen, S., Cohen, A., Zohdy, I., 2016b. Shared Mobility: Current Practices and Guiding Principles. U.S. Department of Transportation, Federal Highway Administration, Washington, DC.

Shaheen, S., Mallery, M., Kingsley, K.J., 2012. Personal vehicle sharing services in North America. Res. Transp. Bus. Manag. 3, 71-81.

Siggelkow, N., 2007. Persuasion with case studies. Acad. Manag. J. 50 (1), 20-24.

Snihur, Y., Tarzijan, J., 2017. Managing complexity in a multi-business-model organization. Long. Range Plan. 51 (1), 50-63.

Sohl, T., Vroom, G., 2017. Mergers and acquisitions revisited: the role of business model relatedness. Adv. Mergers Acquis. 16, 99-113.

Stahel, W.R., 2016. The circular economy. Nature 531 (7595), 435-438.

Stake, R.E., 2005. Case studies. In: Denzin, N.E., Lincoln, Y.S. (Eds.), The Sage Handbook of Qualitative Research. Sage, Thousand Oaks, CA, pp. 443-466.

Strauss, A., Corbin, J., 1990. Basics of Qualitative Research: Grounded Theory Procedures and Techniques. Sage, London, UK.

Teece, D.J., 2010. Business models, business strategy and innovation. Long. Range Plan. 43 (2-3), 172-194.

Van Alstyne, M.W., Parker, G.G., Choudary, S.P., 2016. Pipelines, platforms, and the new rules of strategy. Harv, Bus. Rev. 94 (4), 54-62.

Vaskelainen, T., Piscicelli, L., 2018. Online and offline communities in the sharing economy. Sustain. 10 (8), 2927-2945.

Wilhelms, M.-P., Henkel, S., Falk, T., 2017. To earn is not enough: a means-end analysis to uncover peer-providers' participation motives in peer-to-peer carsharing. Technol. Forecast. Soc. Change 125, 38-47.

Yin, R.K., 2018. Case Study Research and Applications: Design and Methods. Sage, London.

Zervas, G., Proserpio, D., Byers, J.W., 2017. The rise of the sharing economy: estimating the impact of airbnb on the hotel industry. J. Mark. Res. 54 (October), $687-705$ 